\title{
Erratum to: High tie versus low tie in rectal surgery: comparison of anastomotic perfusion
}

\author{
Niels Komen • Juliette Slieker • Peter de Kort • J. H. W. de Wilt • \\ Erwin van der Harst • Peter-Paul Coene • Martijn P. Gosselink • Geert Tetteroo • \\ Eelco de Graaf • Ton van Beek • Rene den Toom • Wouter van Bockel • Cees Verhoef • \\ Johan F. Lange
}

Published online: 27 April 2011

(C) Springer-Verlag 2011

\section{Erratum to: Int J Colorectal Dis}

\section{DOI 10.1007/s00384-011-1188-6}

Due to an oversight on the part of the authors, N. Komen, J. Slieker, P. de Kort, J. H. W. de Wilt, E. van der Harst, P.P Coene, M. Gosselink, G. Tetteroo, E. de Graaf, T. van Beek, R. den Toom, W. van Bockel, C. Verhoef, J.F. Lange, an incorrect name of one of the co-authors was published in the manuscript entitled "High tie versus low tie in rectal surgery: comparison of anastomotic perfusion", Int J Colorectal Dis DOI 10.1007/s00384-011-1188-6.

The correct name of the author is M.P. Gosselink instead of M. Gosselink.

The online version of the original article can be found at http://dx.doi. org/10.1007/s00384-011-1188-6.

\footnotetext{
N. Komen $(\bowtie) \cdot$ J. Slieker $\cdot$ P. de Kort $\cdot$ J. H. W. de Wilt $\cdot$

W. van Bockel · C. Verhoef · J. F. Lange

Department of Surgery, University Medical Center Rotterdam,

Erasmus MC, Rotterdam, The Netherlands

e-mail: nielskomen@hotmail.com

E. van der Harst • P.-P. Coene $\cdot$ M. P. Gosselink

Department of Surgery, Maasstad Ziekenhuis,

Rotterdam, The Netherlands

G. Tetteroo $\cdot$ E. de Graaf

Department of Surgery, IJsselland Ziekenhuis,

Capelle aan den, IJssel, The Netherlands

T. van Beek $\cdot$ R. den Toom

Department of Surgery, Ruwaard van Putten Ziekenhuis,

Spijkenisse, The Netherlands

J. H. W. de Wilt

Department of Surgery,

Radboud University Nijmegen Medical Center,

Nijmegen, The Netherlands
} 